\title{
HUBUNGAN MEMBACA INTENSIF DENGAN MENEMUKAN STRUKTUR TEKS FABEL PADA SISWA KELAS VII SMP NEGERI 2 RANTAU SELATAN KABUPATEN LABUHANBATU TAHUN PELAJARAN 2020-2021
}

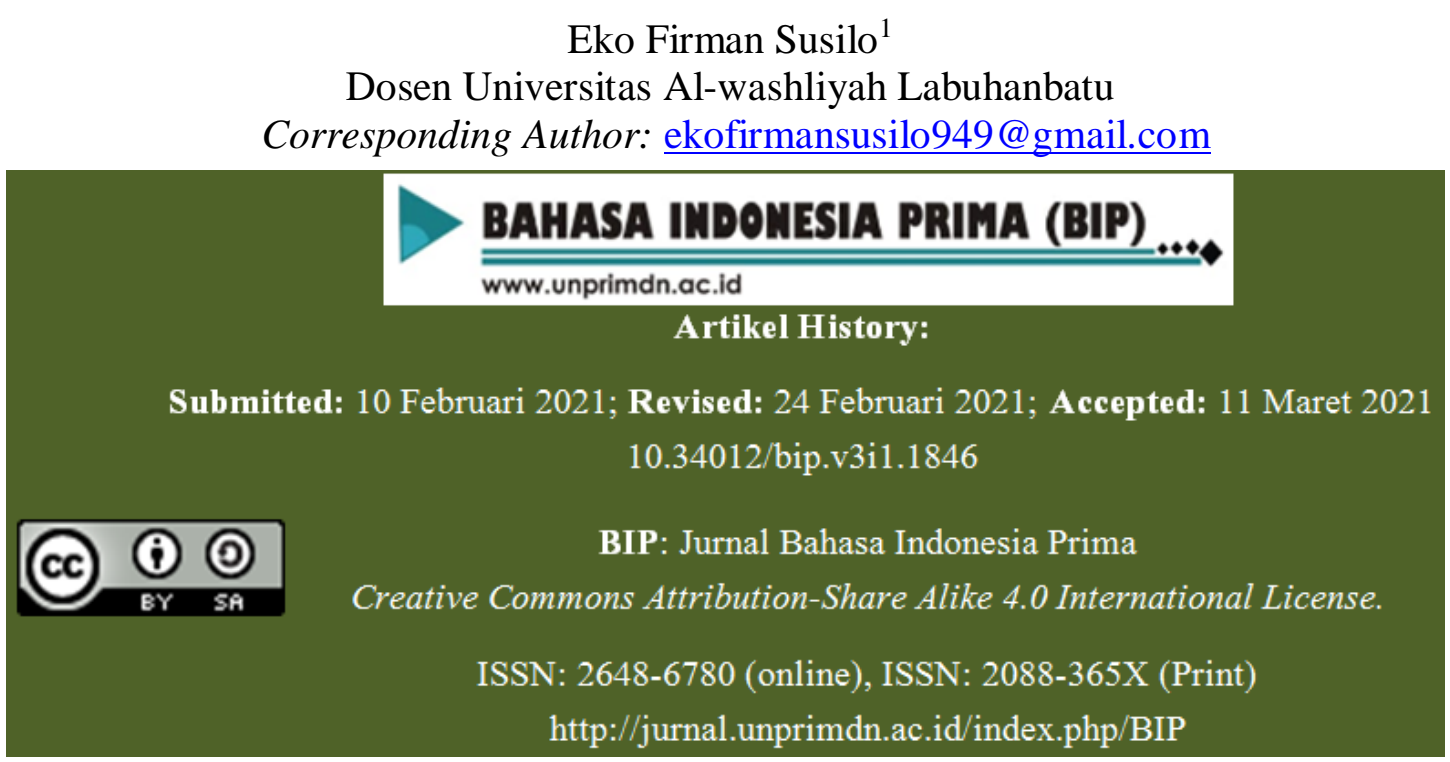

Abstrak-Penelitian ini bertujuan untuk mengetahui hubungan membaca intensif dengan menemukan struktur teks fabel pada siswa kelas VII SMP Negeri 2 Rantau Selatan Kabupaten Labuhanbatu Tahun Pelajaran 2020-2021. Populasi dalam penelitian ini diambil sebesar 25\% dari seluruh siswa kelas VII yang berjumlah 323 siswa, sehingga yang mengikuti penelitian adalah 323 × $25: 100=80$ siswa. Instrumen yang digunakan untuk mengumpulkan data penelitian ini adalah tes pilihan berganda dengan jumlah soal 10 dan essay tes 10 soal untuk membaca intensif dan menemukan struktur teks fabel. Teknik analisis data yang digunakan adalah analisis korelasi Pearson dengan rumus product Moment. Terdapat hubungan yang signifikan antara membaca intensif dengan menemukan struktur teks fabel pada siswa kelas VII SMP Negeri 2 Rantau Selatan, dalam penelitian ini semua telah terbukti dapat diterima kebenaranya.

Kata kunci: membaca intensif, struktur teks fabel.

\section{A. Pendahuluan}

Pendidikan merupakan media yang sangat berperan penting menciptakan manusia yang berkualitas dan berpotensi, melalui pendidikan akan terjadi proses pendewasaan diri sehingga didalam proses pengambilan keputusan terhadap suatu masalah yang dihadapi selalu disertai dengan rasa tanggung jawab yang besar. Yang hakikatnya manusia merupakan hasil pendidikan yang akan menjadi sumber daya pembangunan, dan sebagai warga negara Indonesia haruslah mampu berkomunikasi dan berbahasa dengan baik secara lisan 
maupun tulisan dan membaca adalah salah satu faktor yang sangat menunjang dalam melakukan kegiatan komunikasi non lisan atau tulisan. Oleh karena itu, seseorang perlu belajar cara berkomunikasi dan berbahasa dengan baik seperti membaca intensif, dalam pelajaran Bahasa dan Sastra Indonesia membaca telah menjadi bagian yang sangat besar dan kita dapat menyadarinya dengan jelas betapa besar hubungan membaca dalam pelajaran Bahasa dan Sastra Indonesia, bahwasannya dari sebagian besar anak didik SMP Negeri 2 Rantau Selatan belum mampu memberikan hasil pengamatan dari apa yang telah mereka baca. Seharusnya dengan membaca intensif anak didik dapat mengembangkan dan menyimpulkan gagasan, ide, serta menangkap makna, misalnya anak didik dapat menangkap dan menyimpulkan makna dengan ringkas dari apa yang telah mereka baca.

Keberhasilan sekolah dapat dilihat dari hasil belajar siswa dari prestasi belajarnya, keberhasilan belajar siswa sangat dipengaruhi oleh kemampuan siswa itu sendiri dalam menggunakan kemampuannya masing-masing. Berdasarkan keterangan, dalam mata pelajaran Bahasa dan Sastra Indonesia kegiatan pembelajarannya masih dilakukan secara tradisional, pembelajaran lebih ditekankan pada kegiatan ceramah yang bersifat sentral yang artinya guru dijadikan sebagai pusat atau yang mengendalikan pembelajaran. Kegiatan ini mengakibatkan siswa kurang ikut berpartisipasi dalam kegiatan pembelajaran yang cenderung menjadikan mereka cepat bosan dan malas belajar. Seperti yang sudah tertera pada tujuan pendidikan nasional sebagaimana diatur dalam Undang -Undang Nomor 20 Tahun 2003 pada pasal 1 ayat 1 yang berbunyi Pendidikan adalah usaha sadar dan terencana untuk mewujudkan suasana belajar dan proses pembelajaran agar peserta didik secara aktif mengembangkan potensi dirinya untuk memiliki spiritual, pengendalian diri, kepribadian, kecerdasan, akhlak mulia, serta keterampilan yang diperlukan dirinya, masyarakat, bangsa dan negara.

Untuk mewujudkan tujuan pendidikan tersebut perlu peningkatan di berbagai sektor yaitu salah satunya pendidikan yang bersifat formal,baik itu disekolah negeri maupun swasta. Keberhasilan sekolah dapat dilihat dari hasil belajar siswa dari prestasi belajarnya. Keberhasilan belajar siswa sangat dipengaruhi oleh kemampuan siswa itu sendiri dalam menggunakan setiap kemampuannya masing-masing. Kenyataan di lapangan seperti di SMP Negeri 2 Rantau Selatan dalam mata pelajaran Bahasa Indonesia kegiatan pembelajarannya masih dilakukan secara klasikal atau tradisional. Kegiatan ini mengakibatkan siswa kurang ikut berpartisipasi dalam kegiatan pembelajaran yang cenderung menjadikan mereka cepat bosan dan malas belajar. Jadi kemampuan membaca intensif merupakan pembelajaran yang terpadu untuk memberikan pengalaman bermakna kepada anak didik dan diharapkan akan berguna bagi anak didik dalam kehidupan sehari-hari.

Kemampuan berbahasa khususnya membaca intensif dirasakan sebagai suatu hal yang sangat penting dalam proses belajar mengajar bidang studi Bahasa dan Satra Indonesia pada tingkat SMP. Kondisi ini sangat wajar karena kemampuan membaca 
intensif dapat dijadikan barometer standar dalam mengukur tingkat kemampuan siswa dalam bidang Bahasa dan Sastra Indonesia. Keberhasilan proses kegiatan belajar mengajar pada pembelajaran Bahasa dan sastra Indonesia dapat diukur dari keberhasilan siswa yang mengikuti kegiatan pembelajaran tersebut, yaitu dari tingkat pemahaman, penguasaan materi serta prestasi belajar siswa. Semakin tinggi pemahaman dan penguasaan materi serta prestasi belajar maka semakin tinggi keberhasilan pembelajaran.

Kemampuan membaca intensif pada masa kini sudah menjadi alternatif penting bagi seorang guru, sebab dengan menggunakan kemampuan pembelajaran seorang guru diharapkan dapat menciptakan suasana yang menyenangkan dan melibatkan siswa untuk aktif dalam proses belajar dan diharapkan akan mampu meningkatkan kemampuan siswa dalam membaca intensif yang juga secara otomatis akan meningkatkan prestasi belajar siswa pada pelajaran Bahasa dan Sastra Indonesia.

Berangkat dari latar belakang permasalahan diatas, maka penulis mengadakan penelitian dengan judul yaitu" Hubungan Membaca Intensif dengan Menemukan Struktur Teks Fabel."

Agar penelitian ini lebih efektif, efisien, terarah dan dapat dikaji lebih mendalam maka diperlukan pembatasan masalah, melihat banyaknya faktor yang mempengaruhi hasil belajar siswa pada pelajaran Bahasa dan Sastra Indonesia maka penelitian ini dibatasi pada "Hubungan membaca intensif dengan menemukan struktur teks fabel pada siswa kelas VII SMP Negeri 2 Rantau Selatan”.
Berdasarkan latar belakang masalah di atas maka dapat dirumuskan masalah sebagai berikut: apakah terdapat hubungan yang signifikan antara membaca intensif dengan menemukan struktur teks fabel pada siswa kelas VII SMP Negeri 2 Rantau Selatan? Dan berapa besar hubungan signifikan antara membaca intensif dengan menemukan struktur teks fabel pada siswa kelas VII SMP Negeri 2 Rantau Selatan?

\section{B. Metode Penelitian}

Penelitian ini akan dilaksanakan di SMP Negeri 2 Rantau Selatan yang beralamatkan di jalan H.M. Said Perdamean Sigambal Kabupaten Labuhanbatu pada tahun pembelajaran 2020-2021, sedangkan waktu penelitian dilakukan pada bulan Oktober-November tahun ajaran 2020-2021.

Menurut Sugiono (2012:117), populasi adalah wilayah generalisasi yang terdiri atas obyek / subyek yang mempunyai kualitas dan karakteristik tertentu yang ditetapkan oleh peneliti untuk dipelajari dan kemudian ditarik kesimpulannya.

Menurut Arikunto (2010:173), populasi adalah keseluruhan subjek penelitian. Apabila seseorang ingin meneliti semua elemen yang ada diwilayah penelitian, maka penelitiannya merupakan penelitian populasi. Studi atau penelitiannya juga disebut studi populasi atau studi sensus. Sedangkan menurut Tatang (2009:218), populasi adalah jumlah orang atau penduduk didalam suatu daerah.

Berdasarkan pendapat di atas, penulis mengambil populasi siswa kelas VII SMP Negeri 2 Rantau Selatan T.A 2020-2021 
yang berjumlah 8 kelas dengan perincian sebagai berikut.

Tabel I

Populasi Penelitian

\begin{tabular}{|c|c|c|}
\hline No & Kelas & Jumlah siswa \\
\hline 1 & VII-1 & 36 \\
\hline 2 & VII-2 & 36 \\
\hline 3 & VII-3 & 41 \\
\hline 4 & VII-4 & 42 \\
\hline 5 & VII-5 & 42 \\
\hline 6 & VII-6 & 42 \\
\hline 7 & VII-7 & 42 \\
\hline 8 & VII-8 & 42 \\
\hline & Total & 323 \\
\hline
\end{tabular}

Sumber : Data Base Sekolah

Menurut Sugiono (2012:118), menyatakan bahwa sampel adalah bagian dari jumlah dan karakteristik yang dimiliki oleh populasi tersebut. Bila populasi besar, dan penelitian tidak mungkin mempelajari semua yang ada pada populasi, misalnya keterbatasan dana, tenaga dan waktu, maka peneliti dapat menggunakan sampel yang diambil dari populasi itu, kesimpulannya akan dapat diberlakukannya untuk populasi. Untuk itu sampel yang diambil dari populasi harus betul-betul representatif (mewakili). Sedangkan menurut Arikunto (2010:174), sampel adalah sebagian atau wakil populasi yang diteliti. Mengambil sampel 20 / $25 \%$ dari populasi di atas maka akan diambil sampel 80 siswa dari kelas VII SMP Negeri 2 Rantau Selatan.

TABEL 2

SAMPEL PENELITIAN

SAMPEL PENELITIAN
\begin{tabular}{|c|c|c|}
\hline No & Kelas & Jumlah Siswa \\
\hline 1 & VII-1 & 10 \\
\hline 2 & VII-2 & 10 \\
\hline 3 & VII-3 & 10 \\
\hline 4 & VII-4 & 10 \\
\hline 5 & VII-5 & 10 \\
\hline 6 & VII-6 & 10 \\
\hline 7 & VII-7 & 10 \\
\hline 8 & VII-8 & 10 \\
\hline \multicolumn{2}{|c|}{ Jumlah } & 80 \\
\hline
\end{tabular}
Sampel penelitian pada kelas VII menggunakan sistem acak

Sampel penelitian pada kelas VII menggunakan sistem acak
Berdasarkan dari tujuan dan kerangka teori dalam penelitian ini, maka penulis menggunakan 2 variabel yaitu variabel bebas dan terikat. Variabel bebas adalah faktor yang mempengaruhi dan variabel terikat adalah faktor yang dipengaruhi.Sesuai dengan masalah penelitian ini, maka penulis menetapkan variabel bebas dan terikat seperti berikut ini: 1.Varibel bebas (x) variabel yang berhubungan atau yang menjadi sebab munculnya variabel terikat. Variabel (x) pada penelitian ini adalah membaca intensif. 2. Variabel terikat (y) merupakan variabel yang mempunyai hubungan akibat adanya variabel bebas. Pada penelitian ini, variabel (y) adalah menemukan struktur teks fabel. Pada penelitian ini, peneliti menggunakan jenis penelitian deskriptif (correlation). Menurut Sugiyono (2008:11), pengertian dari penulisan deskriptif korelasi (correlation) adalah penelitian yang dilakukan oleh peneliti untuk mengetahui tingkat hubungan antara dua variabel atau lebih tanpa melakukan perubahan, tambahan atau manipulasi terhadap data yang memang sudah ada.

Dalam penelitian ini instrumen yang digunakan adalah tes objektif (pilihan berganda) dan (essay test). Menurut Sugiono (2012:308), mengatakan bahwa pengumpulan data merupakan langkah yang paling utama dalam penelitian, karena tujuan utama dari penelitian adalah mendapatkan data. Tanpa mengetahui teknik pengumpulan data, maka peneliti tidak akan mendapatkan data yang memenuhi standar data yang ditetapkan. Menurut Arikunto (2010:193), tes adalah serentetan pertanyaan 
atau latihan serta alat lain yang digunakan untuk mengukur keterampilan, pengetahuan intelegensi, kemampuan atau bakat yang dimiliki oleh individu atau kelompok, seperti kegiatan membaca intensif dan kemampuan menemukan struktur teks fabel.

Tes untuk mengumpulkan data yang sifatnya mengevaluasi hasil suatu proses atau untuk mengetahui kondisi awal sebelum terjadinya suatu proses maka digunakan pre test (sebelum proses) dan sesudah proses digunakan post test (setelah proses). Dalam penelitian ini test perlakuan yaitu perlakuan yang tidak menggunakan kemampuan pembelajaran dan perlakuan yang menggunakan kemampuan pembelajaran. Nantinya hasil tes yang dilakukan dibandingkan untuk memperoleh apakah kemampuan pembelajaran yang digunakan peneliti berpengaruh terhadap hasil belajar siswa.

Jumlah siswa yang diberikan penelitian ini adalah 80 siswa dari kelas VII SMP Negeri 2 Rantau Selatan. Teknik penelitian dilakukan dengan menggunakan dua perlakuan, perlakuan yang pertama peneliti tidak menggunakan kemampuan pembelajaran, perlakuan yang kedua peneliti menggunakan kemampuan pembelajaran atau pemahaman yaitu menemukan struktur teks fabel. Desain yang digunakan dalam penelitian ini yaitu one group pretestposttest design. Menurut Suryabrata (2012:101), dalam rancangan ini pertamatama dilakukan pengukuran, lalu dikenakan perlakuan untuk jangka waktu tertentu, kemudian dilakukan pengukuran untuk kedua kalinya. Rancangan ini dapat digambarkan sebagai berikut:

Pretest Treatmean Posttest

\section{T1 $\quad \mathrm{X}$}

T2

Keterangan :

T1: yaitu pre test, untuk mengukur mean prestasi belajar sebelum subjek dikenakan perlakuan pembelajaran.

$\mathrm{X}$ : yaitu proses belajar dengan diskusi untuk pemahaman, dengan jangka waktu tertentu.

T2: yaitu post test, untuk mengukur mean prestasi belajar setelah subjek dikenakan perlakuan pembelajaran.

Setelah data yang dibutuhkan terkumpul, langkah selanjutnya adalah menganalisa data hasil penyaringan tes. Analisis dapat merupakan puncak dari penyelesaian penelitian, sebab data dianalisa, maka ketahuilah apakah hipotesis diterima atau ditolak.

Berdasarkan uraian diatas, dalam penyusunan penelitian ini sangat perlu teknik analisa data. Untuk mendeskripsikan data dan pengujian hipotesis dalam penelitian ini digunakan teknik deskriptif eksploratif (pengolahan data secara kemampuan).

Adapun pengolahan data adalah sebagai berikut: 1. menghitung skor pemahaman membaca intensif. 2. menghitung skor kemampuan menemukan struktur teks fabel. 3. menghitung koefisien korelasi product momen dari person's.

Adapun rumusnya adalah sebagai berikut

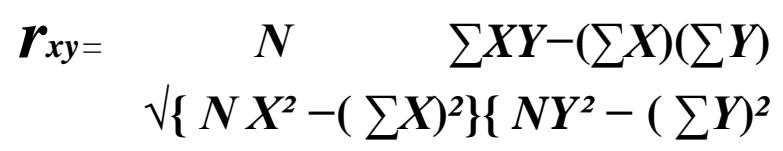

Keterangan : 
r: Korelasi antara hubungan membaca intensif dengan menemukan struktur teks fabel

$\mathrm{x}$ : Jumlah deviasi skor kegiatan membaca intensif

y: Jumlah deviasi skor menemukan struktur teks fable

$\mathrm{N}$ : Jumlah sampel

$\mathrm{x}^{2}$ : Jumlah kuadrat dari deviasi skor kegiatan membaca intensif

$\mathrm{y}^{2}$ : Jumlah kuadrat dari deviasi skor menemukan struktur teks fabel

$\mathrm{x}^{2} \quad \mathrm{y}^{2}$ : Jumlah semua perkalian pasanganpasangan deviasi skor kegiatan membaca intensif dengan menemukan struktur teks fabel

$0,2-0,4:$ Rendah

$0,5-0,6:$ Sedang

$0,7-0,8$ : Tinggi

$0,9-1$ : Sangat tinggi

\section{Hasil dan Pembahasan Penelitian}

Setelah diadakan penelitian terhadap permasalahan yang diambil maka diperoleh data masing-masing tentang Membaca Intensif sebagai variabel $\mathrm{X}$ dan Menemukan Struktur Teks Fabel sebagai variabel Y. Sebab di dalam suatu penelitian salah satu langkah yang ditempuh adalah pengolahan data, data diperoleh setelah adanya diadakan penelitian. Dalam pelaksanaan penelitian diperlukan alat pengumpul data. Adapun alat pengumpulan data pada penelitian ini adalah tes. Data penulis digunakan untuk membuktikan hipotesis membaca intensif dan data ini nantinya akan dikorelasikan dengan hasil tes menemukan struktur teks fabel. Hasil korelasi nantinya yang menjadi titik tolak hipotesis diterima atau ditolak.
Siswa yang mengikuti tes berjumlah 80 orang, materi tes ini mencakup tes mengenai membaca intensif dan menemukan struktur teks fabel. Tes yang diajukan berjumlah 20 soal yang berbentuk tes objektif dengan 10 soal pilihan berganda dan 10 essay tes (soal tes dapat dilihat pada lampiran).

Setelah dilakukannya pengumpulan data, maka akan diketahui seberapa besar skor yang dijawab benar oleh para siswa yang dikenakan penelitian. Cara menemukan skor adalah dengan menghitung jawaban yang benar saja dan diberi skor 1 dan nilainya. Misalnya si A menjawab benar soal 18, maka skor si A sama dengan 18. Jadi skor yang tertinggi adalah 20. Untuk menentukan peringkat nilai, setiap skor yang benar diberi nilai 5 ( lima ). Misalnya si A mendapat skor 18 maka diberi nilai 90.

\section{Pengolahan Data Skor Tes Membaca Intensif ( $X$ )}

Dalam melakukan pengolahan data penulis akan mengetahui Jumlah skor yang benar dan skor rata-rata siswadalam tes membaca intensif (pre test).Setelah dilakukan pengumpulan data maka data yang dapat diketahui adalah jumlah keseluruhan skor tes yang benar berjumlah 675, sedangkan skor rata-ratanya adalah $675: 80=8,4375$.

\section{Pengolahan Data Skor Tes Menemukan Struktur Teks Fabel ( Y )}

Data yang kedua yang digunakan untuk membuktikan hipotesis ini adalah tes menemukan struktur teks fabel (post test). Adapun hasil pengolahan data dari setiap 
responden yaitu jumlah keseluruhan skor tes yang benar dalammenemukan struktur teks fabel adalah 1165, sedangkan skor rataratanya adalah $1165: 80=14,56$.

Setelah memperoleh data dan pengolahannya, maka selanjutnya langkah yang penulis lakukan adalah mengkorelasikan kedua variabel, yaitu variabel $\mathrm{X}$ dengan variabel $\mathrm{Y}$. Sebelum kedua variabel itu dikorelasikan, terlebih dahulu penulis mencari mean (rata-rata) skor setiap siswa. Hal ini dimaksudkan untuk mendapatkan mean $\mathrm{X}$ dan $\mathrm{Y}$, sehingga pengkorelasian dapat dikerjakan dengan mudah dan untuk memudahkan perhitungan, maka penulis terlebih dahulu membuat tabel koefisien korelasi dari tes membaca intensif dan tes menemukan struktur teks fabel. Sebaran data dari hasil pengolahan data dapat dilihat pada tabel yang terdapat pada lampiran.

Berdasarkan pada tes membaca intensif (pre test), maka diketahui nilai tertinggi yang diperoleh siswa adalah 75 dan yang terendah 15.Berdasarkan tes yang ada, hasil belajar siswa mendapatkan nilai keseluruhan sebesar 3375 dan nilai rataratanyasebesar 42,18 Nilai tersebut belum mencapai Kriteria Ketuntasan Minimal (KKM) yaitu 70 dan rentang tabulasi dapat dilihat pada tabel berikut :

TABEL 3

PEROLEHAN SKOR VARIABEL X

\begin{tabular}{|c|c|c|c|}
\hline \multicolumn{4}{|c|}{ PEROLEHAN SKOR VARIABEL X } \\
\hline Rentang & F. Absolut & F.Relatif & Kategori \\
\hline 100 & 0 & $0 \%$ & Sangat Baik \\
\hline $90-95$ & 0 & $0 \%$ & Baik Sekali \\
\hline $80-85$ & 0 & $0 \%$ & Baik \\
\hline $70-75$ & 2 & $2,5 \%$ & Cukup \\
\hline $60-65$ & 10 & $12,5 \%$ & Kurang Baik \\
\hline $50-55$ & 16 & $20 \%$ & Kurang Sekali \\
\hline $15-45$ & 52 & $65 \%$ & Buruk \\
\hline \multicolumn{2}{|c|}{ Jumlah 80} & \multicolumn{2}{|c|}{$100 \%$} \\
\hline
\end{tabular}

Dari tabel di atas dapat diperinci menjadi 7 kategori yaitu sangat baik 0 orang $(0 \%)$, baik sekali 0 orang (0\%), kategori baik 0 orang $(0 \%)$, kategori cukup 2 orang $(2,5 \%)$, kategori kurang baik 10 orang $(12,5 \%)$, kategori kurang sekali 16 orang (20\%) dan kategori buruk 52 orang $(65 \%)$. Selanjutnya sampel penelitian dikenakan perlakuan yang kedua yaitu dengan menemukan struktur teks fabel (post test). Maka diperoleh data sesudah perlakuan yaitu jumlah nilai keseluruhan yang berjumlah 5825 dengan nilai rata-rata 72,81. Nilai tersebut telah mencapai Kriteria Ketuntasan Minimal (KKM) yaitu 70 dan nilai siswa dapat dilihat jauh lebih meningkat dari nilai sebelumnya.Secara keseluruhan rentang nilai dapat dilihat pada tabel berikut:

TABEL 4
\begin{tabular}{|c|c|c|c|}
\hline PEROLEHAN SKOR VARIABEL Y \\
\hline Rentang & F.Absolut & F.Relatif & Kategori \\
\hline $81-95$ & 18 & $22,5 \%$ & Sangat baik \\
\hline $76-80$ & 11 & $13,75 \%$ & Baik sekali \\
\hline $66-75$ & 18 & $22,5 \%$ & Baik \\
\hline $60-65$ & 33 & $41,25 \%$ & Cukup \\
\hline Jumlah & 80 & \multicolumn{3}{|c}{$100 \%$} \\
\hline
\end{tabular}

Dari tabel di atas dapat diperinci menjadi 4 kategori yaitu kategori sangat baik 18 orang $(22,5 \%)$ kategori baik sekali 11 orang $(13,75 \%)$ kategori baik 18 orang $(22,5 \%)$ dan kategori cukup 33 orang $(41,25 \%)$.

Setelah penulis mendapatkan hasil dari pengolahan data, berupa nilaikeseluruhan dari tes membaca intensif dan tes menemukan struktur teks fabel. Selanjutnya penulis akan mengkorelasikan kedua variabel tersebut seperti yang telah ada pada lampiran, yaitu dengan jumlah responden 80 
dan jumlah keseluruhan $\sum X$ 3375, $\sum Y$ 5825, XY 248250, $X^{2} 154825, Y^{2} 434225$.

Perhitungan Koefisien Korelasi Antar Variabel adalah sebagai berikut:

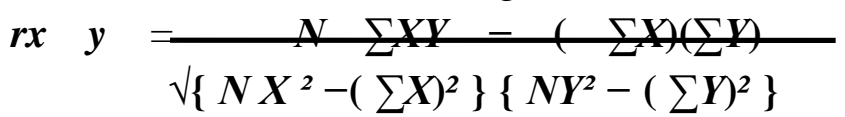

$=80.248250-3375.5825$

$\sqrt{ }\{80.154825-(11390625)\}\{80.434225-(33930625)\}$

$=\frac{200625}{\sqrt{(995375)(807375)}}$

$=0,2238$

$=0,223$

Dengan demikian telah diketahui bahwasannya koefisien korelasi $\mathrm{X}$ terhadap $\mathrm{Y}$ adalah signifikan artinya $r$ hitung lebih besar dari $r_{\text {tabel }}(0,223>0,217)$. Ini berarti setiap kali diberi pengetahuan tentang membaca intensif maka kemampuan menemukan struktur teks fabel akan meningkat sebesar 0,223 (rendah). Maka hasil kemampuan belajar siswa tergolong rendah, sementara 0,777 ditentukan oleh faktor lain.

\section{Simpulan}

Dari hasil penelitian yang telah penulis laksanakan serta untuk mendukung hipotesis dan tujuan penelitian yang penulis lakukan, berikut ini penulis mengutarakan kesimpulan dan saran-saran yang dirumuskan secara keseluruhan.

1. Terdapat hubungan yang signifikan antara membaca intensif dengan menemukan struktur teks fabel yang dilakukan pada siswa kelas VII SMP Negeri 2 Rantau Selatan. Karena telah diketahui jumlah $r_{\text {hitung }}$ yaitu 0,223 , maka dari itu terdapat hubungan yang signifikan dari proses penelitian.

2. Terdapat hubungan yang signifikan antara membaca intensif dengan menemukan struktur teks fabel dalam penelitian ini dan semua telah terbukti dapat diterima kebenarannya. Karena telah terbukti jumlah rhitung lebih besar dari $r_{\text {tabel }}(0,223>0,217)$.

Berdasarkan kesimpulan dan memperhatikan hasil penelitian di atas, maka penulis menyarankan sebagai berikut :

1. Setiap siswa hendaknya dimotifasi oleh guru untuk lebih meningkatkan kemampuan membaca, khususnya membaca intensif karena semakin tinggi kemampuan siswa membaca intensif maka semakin tinggi pula siswa memahami dan mengerti apa yang dibacanya.

2. Hendaknya pihak sekolah lebih melengkapi buku-buku di perpustakaan yang menyangkut tentang buku-buku pengetahuan, khususnya tentang keterampilan membaca intensif dan kemampuan menemukan struktur teks fabel

3. Para guru hendaknya lebih meningkatkankemampuan yang ada pada siswa seperti membaca intensif dan menemukan struktur teks fabeluntuk meningkatkan pengetahuan di dalam proses belajar mengajar.

4. Perlu adanya penelitian lebih lanjut yang berhubungan dengan keterampilan membaca intensif dengan kemampuan menemukan struktur teks fabel.

5. Semoga hasil penelitian ini menjadi bahan masukan pada penelitianpenelitian yang relevan di kemudian hari.

\section{Daftar Pustaka}

Adi K, Dwi. 2001. Kamus Praktis Bahasa Indonesia. Surabaya: Fajar Mulya. 
Arikunto. 2010. Prosedur Penelitian. Jakarta: Rineka Cipta.

Depdikbud. 2014. Bahasa Indonesia Wahana Pengetahanu. Jakarta: Edisi Revisi.

Lestari dkk. 2005. Pendidikan Bahasa dan Sastra Indonesi. Klaten: Intan Pariwara.

Nurhadi dkk. 2007. Bahasa dan Sastra Indonesia. Jakarta: Erlangga.

Rahim, Flarida. 2008. Pengajaran Membaca di Sekolah Dasar. Jakarta: PT Bumi Aksara.

Sugihastuti. 1996. Serba-Serbi Cerita AnakAnak. Yogyakarta: Pustaka Pelajar .

Sugiyono. 2008. Statistik. Bandung: Alfabeta.

Sugiono. 2012. Metode Penelitian Pendidikan. Bandung: Alfabeta.
Sutarni dkk. 2013. Bahasa Indonesia. Bogor: Quadra.

Suryabrata, Sunardi. 2003. Metodologi Penelitian. Jakarta: Rajawali Pers.

Tarigan. 2010. Membaca Sebagai Suatu Keterampilam Berbahasa. Bandung: Angkasa.

Tatang dkk. 2009. Bahasa Indonesia Bahasa Negeriku. Solo: Platinum.

Undang-undang RI Nomor 14 Tahun 2005 dan Peraturan Menteri Pendidikan Nasional RI Nomor 11 Tahun 2011. Bandung: Fokusindo Mandiri.

Yundia, Siti zahra. 2003. Unsur Ditaksis Fabel Nusantara. Jakarta: Balai Pustaka.

Zabadi dkk. 2014. Bahasa Indonesia. Jakarta: Kemendikbud. 